\title{
Efektivitas Friction Massage Terhadap Mengurangi Nyeri Pada Kasus Myofascial Trigger Point Syndrome Otot Upper Trapezius
}

\author{
Aditya Denny Pratama \\ Fisioterapi Program Pendidikan Vokasi, Universitas Indonesia, Depok Jawa Barat \\ Email: aditya.denny@vokasi.ui.ac.id
}

\begin{abstract}
Background: Myofascial trigger point syndrome is a musculoskeletal disorder characterized by the presence of a trigger point in a sensitive area within the skeletal muscle band linkages, if pressure is applied to the area it will cause specific pain at a point that is pressed (tenderness). Myofascial trigger point syndrome is influenced both by mechanism and by positioning factors. Myofascial trigger point syndrome upper trapezius muscle radiates along the upper back and neck, behind the ears and at the temples. Methods: The research method used is in the form of a case study with 1 patient who was given physiotherapy intervention and evaluation 4 times. To overcome the problem of muscle pain in bilateral trapezius m.upper in this study, using manual physiotherapy intervention therapy in the form of friction massage. Result: The results obtained, there was a decrease in tenderness in the upper trapezius muscle VAS 5 during the first evaluation to VAS 2 at the fourth evaluation with an average VAS value pre and post after one month for four interventions, namely 1.72. The MDC value (95) is 0.196 and the MCID range is 0.88-1.7, and 1.46-2.28. Conclusion: Based on these results, it can be concluded that physiotherapy intervention with the manual method of therapy, friction massage is considered effective in reducing pain in patients with myofascial trigger point syndrome, upper trapezius muscle with visual analogues scale (VAS) parameters.
\end{abstract}

Keyword : Myofascial Trigger Point Syndrome, Manual Therapy, Friction Massage

\begin{abstract}
ABSTRAK
Latar Belakang: Myofascial trigger point syndrome merupakan salah satu gangguan muskuloskeletal yang ditandai dengan adanya trigger point (titik nyeri) di area yang sensitif di dalam taut band otot skeletal, jika diberikan tekanan pada area tersebut akan menimbulkan nyeri yang spesifik pada suatu titik yang ditekan (tenderness). Myofascial trigger point syndrome dipengaruhi baik secara mekanisme maupun faktor presdiposisi. Myofascial trigger point syndrome otot upper trapezius menjalar di sepanjang punggung atas dan leher, di belakang telinga dan di pelipis. Metode: Metode penelitian yang digunakan adalah dalam bentuk studi kasus dengan 1 orang pasien yang diberikan intervensi fisioterapi dan evaluasi sebanyak 4 kali. Untuk mengatasi permasalahan nyeri otot di m.upper trapezius bilateral dalam penelitian ini menggunakan intervensi fisioterapi manual terapi berupa friction massage. Hasil: Hasil yang didapatkan, adanya penurunan nyeri tekan pada otot upper trapezius VAS 5 saat evaluasi ke I ke VAS 2 pada evaluasi ke IV dengan nilai VAS rata-rata pre dan post setelah satu bulan selama empat kali intervensi, yaitu 1,72. Nilai MDC (95) adalah 0,196 dan rentang MCID adalah 0,88-1,7 dan. 1,46-2,28. Kesimpilan: Berdasarkan hasil tersebut, dapat disimpulkan bahwa intervensi fisioterapi dengan metode manual terapi, friction massage dinilai efektif dalam mengurangi nyeri pada pasien myofascial trigger point syndrome otot upper trapezius yang dengan parameter visual analogues scale (VAS).
\end{abstract}

Kata Kunci : Myofascial Trigger Point Syndrome, Manual Terapi, Friction Massage 


\section{PENDAHULUAN}

Sejak awal Maret 2020, kasus pertama Covid-19 masuk ke Indonesia sehingga pada pertengahan bulan Maret 2020, pemerintah memberlakukan lockdown disejumlah daerah di Indonesia, seperti masjid, rumah makan, dan perkantoran serta menganjurkan masyarakat untuk \#dirumahaja. Salah satu yang terdampak karena adanya kebijakan untuk \#dirumahaja, yaitu karyawan perkantoran yang harus bekerja dari rumah atau work from home (WFH). WFH dapat membuat para karyawan perkantoran menjadi jarang gerak dan seringkali bekerja dengan postur membungkuk dan forward head. Jika hal tersebut dilakukan secara berulang dapat memicu gangguan kesehatan. Salah satu diantaranya adalah gangguan muskuloskeletal. Salah satu gangguan muskuloskeletal yang sering terjadi adalah myofascial trigger point syndrome.

Myofascial trigger point syndrome adalah salah satu gangguan muskuloskeletal yang ditandai dengan adanya nyeri yang spesifik jika diberi tekanan pada trigger point (titik nyeri) di area yang sensitif di dalam taut band otot skeletal yang ditekan (tenderness). Myofascial trigger point syndrome dapat menyebabkan nyeri lokal, tenderness, tightness, stiffness, nyeri rujukan, dan kelemahan otot yang biasanya terjadi pada otot upper trapezius. ${ }^{1}$ Kasus myofascial trigger point syndrome yang sering dijumpai, yaitu pada otot upper trapezius yang menjalar di sepanjang punggung atas dan leher, di belakang telinga dan di pelipis. ${ }^{2}$

Prevalensi myofascial trigger point syndrome di Amerika Serikat mencapai 30$85 \%$ dan dilaporkan mencapai angka 54\% selama 6 bulan. Individu yang mengalami peningkatan gejala yang terus menerus mencapai 37\%. Dari 96\% dengan keluhan nyeri otot, $74 \%$ disebabkan oleh myofascial trigger point syndrome. Saat ini belum ada data yang pasti untuk prevalensi kasus myofascial trigger point syndrome di Indonesia, namun terdapat sebuah penelitian yang dilakukan di Jakarta terhadap kantoran, 44 orang $(17.93 \%)$ dengan hasil penelitian menyatakan sebanyak $34.1 \%$ positif mengalami myofascial trigger point syndrome atau sekitar $6.72 \%$ dari jumlah seluruh populasi. $^{3}$

Problematika fisioterapi yang sering terjadi pada myofascial trigger point syndrome, yaitu nyeri gerak, nyeri tekan, spasme, keterbatasan range of motion (ROM), dan gengguan postur. Sehingga dibutuhkan intervensi dalam mengurangi masalah tersebut untuk meningkatkan dan mempertahankan kemandirian dalam melakukan aktivitas. Salah satunya melalui tindakan fisioterapi.

Friction massage merupakan teknik massage untuk jaringan dalam (deep tissue) dengan gerakan gerusan kecil-kecil yang bergerak berputar-putar searah dan berlawanan arah jarum jam, serta gerakan melintang ke samping secara supel dah 
kontinyu sehingga seperti spiral. Teknik massage ini dapat dilakukan menggunakan ujung tiga jari (jari telunjuk, jari tengah, jari manis) yang dirapatkan, ibu jari, ujung siku, dan pangkal telapak tangan. Adapun tujuan friction massage untuk mempertahankan mobilitas pada struktur jaringan ligamen, tendon dan otot yang melekat, mengurangi nyeri tekan, melancarkan sirkulasi darah dan pengembalian cairan pada otot, serta meningkatkan fleksibilitas, maupun kemampuan fungsional. ${ }^{4-6}$ Oleh karena itu, studi kasus ini bertujuan untuk menilai efektivitas friction massage terhadap mengurangi myofascial trigger point syndrome otot upper trapezius.

\section{TINJAUAN PUSTAKA}

\subsection{Myofascial Trigger Point Syndrome Otot Upper Trapezius}

Myofascial trigger point syndrome adalah salah satu gangguan muskuloskeletal yang ditandai dengan adanya nyeri yang spesifik jika diberi tekanan pada trigger point (titik nyeri) di area yang sensitif di dalam taut band otot skeletal yang ditekan (tenderness). Myofascial trigger point syndrome dapat menyebabkan nyeri lokal, tenderness, tightness, stiffness, nyeri rujukan, dan kelemahan otot yang biasanya terjadi pada otot upper trapezius. ${ }^{1}$

Kasus myofascial trigger point syndrome yang sering dijumpai, yaitu pada otot upper trapezius yang membentuk seperti jalinan tali dan lunak ketika disentuh atau dipalpasi pada taut band terdapat trigger point sehingga akan menimbulkan refleks ketegangan pada otot tersebut dan dirasakan nyeri yang menjalar (referred pain) dengan pola yang spesifik. Myofascial trigger point syndrome otot upper trapezius menjalar di sepanjang punggung atas dan leher, di

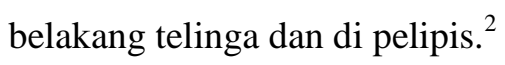

Secara garis besar, terjadinya myofascial trigger point syndrome dipengaruhi secara mekanisme dan faktor presdiposisi. Adapun mekanisme yang dapat menyebabkan myofascial trigger point syndrome, antara lain ${ }^{7,8}$ :

a) Kontraksi otot tingkat rendah

b) Distribusi tekanan intramuscular tidak merata

c) Trauma

Trauma pada jaringan myofascial trigger point syndrome dibagi menjadi dua, yaitu :

a. Trauma makro

Trauma makro merupakan suatu cidera yang terjadi pada otot atau fasia sehingga terjadi proses inflamasi, diikuti dengan adanya produksi dari serabut kolagen sehingga akan terjadi ketegangan dan menurunkan mobilitas pada jaringan myofascial.

b. Trauma mikro

Trauma mikro ketika terjadi cidera yang berulang (repetitive injury) akibat dari suatu kerja yang terus menerus dengan beban yang berlebih.

d) Kontraksi eksentrik dan konsentrik sub maksimal dan maksimal

Faktor presdiposisi yang menyebabkan terjadinya gangguan fungsional myofascial 
trigger point syndrome otot upper trapezius, antara lain faktor internal dan faktor eksternal. Faktor internal merupakan factor yang tidak dapat diubah, seperti usia dan jenis kelamin. Sedangkan factor eksternal cenderung terhadap keseharian yang dapat menyebabkan myofascial trigger point syndrome otot upper trapezius, yaitu lama kerja, postur yang buruk, dan ergonomi kerja. $^{7,8}$

\subsection{Metode dan Teknik Intervensi}

Friction massage merupakan teknik massage untuk jaringan dalam (deep tissue) dengan gerakan gerusan kecil-kecil yang bergerak berputar-putar searah dan berlawanan arah jarum jam, serta gerakan melintang ke samping secara supel dan kontinyu sehingga seperti spiral. Teknik massage ini dapat dilakukan menggunakan ujung tiga jari (jari telunjuk, jari tengah, jari manis) yang dirapatkan, ibu jari, ujung siku, dan pangkal telapak tangan. ${ }^{4}$

Adapun tujuan friction massage untuk mempertahankan mobilitas pada struktur jaringan ligamen, tendon dan otot yang melekat, mengurangi nyeri tekan, melancarkan sirkulasi darah dan pengembalian cairan pada otot, serta meningkatkan fleksibilitas, maupun kemampuan fungsional. ${ }^{5,6}$

\subsection{Pemeriksaan dan Pengukuran}

Pemeriksaan nyeri membantu mengetahui lebih lanjut mengenai intensitas, tipe, seberapa lama nyeri berlangsung untuk menegakkan diagnosa, menentukan rencana terapi, serta mengevaluasi efektivitas terapi yang diberikan. Teknik pengukuran skala nyeri dilakukan dengan berbagai metode, salah satunya dengan VAS (Visual Analogues Pain Rating Scales). VAS merupakan alat ukur yang sederhana untuk mengukur perkiraan intensitas nyeri. Teknik ini menggunakan urutan angka dari 1 sampai 10 untuk menunjukkan nilai tingkatan nyeri. Nilai 1 untuk nyeri ringan dan 10 untuk nyeri paling berat. $^{9}$

\section{METODE PENELITIAN}

Merupakan studi kasus tunggal dengan desain penelitian pre dan post test yaitu membandingkan anatara skor sebelum dan sesudah intervensi friction massage.

\subsection{Subjek}

Seorang wanita berusia 69 tahun dengan diagnosis myofascial trigger point syndrome otot upper trapezius, mengeluhkan nyeri dan kaku pada punggung bagian atas yang awal mula hanya merasakan kaku dan pasien hanya mengganggapnya biasa. Pasien merasakan kaku dan nyeri semakin terasa saat melakukan aktivitas sehari-hari, seperti mengambil benda di atas lemari, kesulitan gerakan salam saat sholat, dan kesulitan untuk melakukan hobinya, yaitu berkebun. Kemudian pada 23 Oktober 2018 pasien datang ke RSUPN Cipto Mangunkusumo dan datang ke poli rehab dan dirujuk untuk dilaser sebanyak 6 kali. Setelah dilaser 6 kali, pasien merasakan kaku dan nyeri tak kunjung membaik, kemudian pasien menjalani dry needling sebanyak 4 kali sejak 12 Desember 2018, namun tetap tidak ada 
perubahan. Pada tanggal 6 Februari 2019, pasien dirujuk ke fisioterapi dan sudah menjalani 3 kali terapi di RSUPN Cipto Mangunkusumo dan sudah merasakan ada penurunan sedikit terhadap nyeri dan kekakuan pada punggung bagian atas. Selain itu, pasien juga rutin kontrol ke poli lain terkait gastrophalangeal reflux yang dideritanya sejak 2015 dan pasien juga memiliki riwayat hipertensi sejak 2015.

Subjek memiliki kesadaran compos mentis, pasien kooperatif dan cara datang pasien mandiri. Setelah dilakukan pemeriksaan umum, vital sign pasien berkesan baik, indek massa tubuh pasien normal dan dilakukan pemeriksaan khusus inspeksi, pasien terdapat abnormal postur karena kebiasaan postur pasien yang buruk ketika beraktivitas. Lalu pada pemeriksaan khusus palpasi, terdapat nyeri tekan pada m.upper trapezius bilateral.

\subsection{Waktu dan Tempat}

Penelitian dilakukan di poli fisioterapi geriatri RSUPN Dr. Cipto Mangunkusumo dan penelitian dilakukan sebanyak 4 kali pertemuan, dimulai 13 Februari - 22 Februari 2019.

\subsection{Penatalaksaan Intervensi}

Intervensi berupa pemberian manual terapi, massage dengan teknik friction selama 7 menit dan dilakukan 2 kali/minggu.

\section{HASIL DAN PEMBAHASAN}

\subsection{Hasil}

Hasil 4 kali evaluasi pemberian friction massage selama 2 minggu pada subjek penelitian didapatkan hasil berupa :

Grafik 1 Evaluasi Nyeri

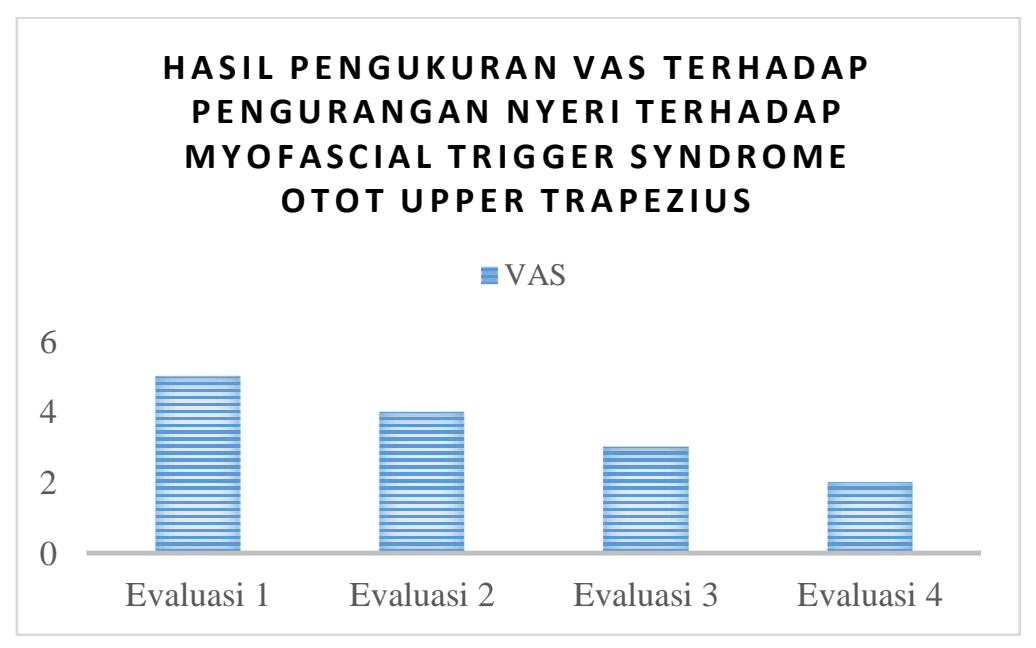

Berdasarkan grafik di atas didapat hasil penurunan nyeri tekan pada otot upper trapezius VAS 5 saat evaluasi ke I ke VAS 2 pada evaluasi ke IV menggunakan friction massage pada kasus myofascial trigger point syndrome otot upper trapezius. 


\subsection{Pembahasan}

Penurunan nyeri pada myofascial trigger point syndrome otot upper trapezius yang diperoleh dengan menggunakan friction massage didukung oleh artikel Nanda C.A. ${ }^{10}$ yang berjudul, "Penerapan myofascial release technique sama baik dengan ischemic compression technique dalam menurunkan nyeri pada sindroma miofasial otot upper trapezius". Hasil penelitian dan analisis data tersebut menyatakan, bahwa penerapan myofascial release technique sama baik dengan ischemic compression technique dalam menurunkan nyeri pada sindroma miofasial otot upper trapezius.

Nilai VAS rata-rata Pre dan Post setelah satu bulan selama empat kali intervensi, yaitu 1,72. Nilai MDC (95) adalah 0,196, dan rentang MCID adalah 0,88-1,7 dan 1,46-2,28.

\section{KESIMPULAN}

Metode manual terapi Friction Massage dinilai efektif dalam mengurangi nyeri pada pasien Myofascial Trigger Point Syndrome Otot Upper Trapezius yang dengan parameter Visual Analogues Scale (VAS).

\section{REFERENSI}

1. Javier Montañez-Aguilera F, ValtueñaGimeno N, Chamón-Sánchez-de-losSilos R, Martínez-Sanchís J, BarriosPitarque C, Bosch-Morell F. Short-term efficacy of Richelli's Painreliever TM on Upper Trapezius Myofascial Trigger
Point in a patient with neck pain- A Case report. J Phys Ther. 2011;3(2):60-9.

2. Sugijanto, Bimantoro A. Perbedaan Pengaruh Pemberian Ultrasound Dan Manual Longitudinal Muscle Stretching Dengan Ultrasound Dan Auto Stretching Terhadap Pengurangan Nyeri Pada Konsisi Sindroma Miofasial Otot Upper Trapezius. J Fisioter. 2008;8(1):5.

3. Nyoman Bagus Arthasusila Wigraha W. Perbedaan Efek Antara Integrated Neuromuscular Inhibition Technique ( Init ) Dengan Myofascial Release Terhadap Nyeri Dan Disabilitas Kasus Myofascial Trigger. J Fisioter. 2017;17(April):9.

4. Muasaroh L. Penatalaksanaan Fisioterapi Pada Myofacial Trigger Point Syndrome Upper Trapezius. 2018;

5. Celik D, Mutlu EK. Clinical implication of latent myofascial trigger point topical collection on myofascial pain. Curr Pain Headache Rep. 2013;17(8).

6. Chamberlain GJ. Cyriax's friction massage: A review. J Orthop Sports Phys Ther. 1982;4(1):16-22.

7. Dommerholt J, Bron C, Franssen J. Myofascial trigger points: An evidence-informed review. J Man Manip Ther. 2006;14(4):203-21.

8. Maruli WO, Sutjana ID, Indrayani AW. Perbandingan Myofascial Release Technique dengan Contract Relax 
Stretching terhadap penurunan nyeri pada sindroma Myofascial otot Upper Trapezius. Maj Ilm Fisioter Indones [Internet]. 2014;2(3):3. Available from: https://ojs.unud.ac.id/index.php/mifi/art icle/view/8470/6314

9. Doi MY, Tano SS, Schultz AR, Borges R, Marchiori LL de M. Efetividade da terapia por acupuntura como tratamento para o zumbido: ensaio clínico aleatorizado. Braz J Otorhinolaryngol [Internet]. 2016;82(4):458-65. Available from: http://dx.doi.org/10.1016/j.bjorl.2016.0
4.002

10. Anggraeni NC. Penerapan Myofascial Release Technique Sama Baik Dengan Ischemic Compression Technique Dalam Menurunkan Nyeri Pada Sindroma Miofasial Otot Upper Trapezius. Maj Ilm Fisioter Indones [Internet]. 2014;2(2):1-12. Available from:

https://doi.org/10.24843/MIFI.2014.v0 2.i02.p04\%0Ahttps://ojs.unud.ac.id/ind ex.php/mifi/article/download/8437/629 $5 /$ 